\title{
The anti-cachectic effect of fatty acids
}

\author{
Matthew D. Barber, James A. Ross and Kenneth C. H. Fearon* \\ University Department of Surgery, Royal Infirmary of Edinburgh, Edinburgh EH3 9YW, UK
}

Patients with advanced cancer frequently exhibit progressive weight loss and this is associated with a shorter survival time and reduced quality of life. Indeed, some patients appear to die of severe wasting rather than as a result of vital organ involvement by tumour (Warren, 1935; DeWys et al. 1980; Oveson et al. 1993b). Severity of weight loss varies markedly with tumour type; for example, some patients with advanced breast cancer actually increase their weight, whereas almost all patients with pancreatic cancer become severely wasted. In a recent survey of patients with unresectable pancreatic cancer we found that $85 \%$ of patients had unintentionally lost weight by the time of diagnosis and that near to the time of death the group as a whole had lost approximately $25 \%$ of their pre-illness weight (Wigmore et al. 1997c). Clearly, in a proportion of individuals with pancreatic cancer such severe weight loss contributes to their demise, and thus it is patients with pancreatic cancer that we have used as a paradigm for cancer cachexia.

The term cachexia is derived from the Greek words 'kakos', meaning 'bad' and 'hexis', meaning 'condition'. The syndrome is characterized by anorexia, early satiety, changes in taste perception, weight loss, weakness, anaemia and oedema (Fearon \& Carter, 1988). Cachexia is not exclusive to cancer, but is also seen in a variety of inflammatory conditions such as sepsis, acquired immunodeficiency syndrome and rheumatoid arthritis (Grunfeld \& Feingold, 1992; Roubenoff et al. 1992; Cangiano et al. 1996).

\section{Mechanisms of weight loss in cancer}

For loss of weight to occur there must be a reduction in energy intake, an increase in energy expenditure or a combination of the two. In pancreatic cancer it would appear that both reduced intake and increased expenditure apply (Falconer et al. 1994; Wigmore et al. 1997d). In uncomplicated starvation there is an adaptation to conserve protein and reduce energy expenditure. In cancer cachexia these adaptations do not appear to compensate adequately, and a situation more akin to the so-called 'metabolic response to trauma' develops, with continuing breakdown of body stores and increased energy expenditure (Falconer et al. 1994; Brennan, 1997). A wide spectrum of changes in nutrient metabolism is seen in weight-losing cancer patients. Insulin resistance, glucose intolerance, increased glucose production and consumption, and increased Cori cycle activity have all been demonstrated (Chlebowski et al. 1982; Edén et al. 1984; Holroyde et al. 1984; Shaw \& Wolfe, 1987). A decrease in lipogenesis is seen due to decreased lipoprotein lipase ( $E C$ 3.1.1.34) activity (Jeevanandam et al. 1986; Vlassara et al. 1986). Protein turnover is altered (Fearon et al. 1988; Melville et al. 1990) and this may be closely related to the development of an hepatic acute-phase response.

At diagnosis about $40 \%$ of patients with advanced pancreatic cancer display an acute-phase protein response. Close to the time of death this proportion rises to $80 \%$ (Falconer et al. 1995). The acute-phase protein response is an alteration in the balance of protein production by the liver, usually in response to injury, trauma or infection, in an attempt to aid the prevention of ongoing tissue damage, the eradication of infecting organisms and the activation of repair processes (Baumann \& Gauldie, 1994). The presence of an acute-phase protein response in pancreatic cancer patients, as measured by an elevated serum C-reactive protein level, is strongly associated with a shorter survival (Falconer $e$ t al. 1995). It has been suggested that an imbalance between the amino acid composition of acute-phase proteins and skeletal muscle, the body's labile amino acid reserve, helps drive the accelerated wasting seen during an acute-phase response (Reeds et al. 1994).

Overall, these metabolic changes result in a diversion of nutrients away from peripheral tissues and increased expenditure of energy. In the acute situation, such as trauma or infection, the net effect is presumably beneficial in supplying the nutrients and proteins to aid the defence of the body, but in a chronic condition such as cancer these changes can lead to accelerated loss of lean tissue.

Anorexia in patients with advanced cancer can often be due to obstruction of the gastrointestinal tract, pain, depression, anxiety, steatorrhoea, constipation, general debility and the effects of treatments such as opiates, radiotherapy and chemotherapy. However, there remain many patients with advanced cancer in whom there is no overt cause of a reduced food intake. Weight loss can begin early in the course of malignant disease and the degree of wasting may correlate poorly with tumour burden. Thus, it would appear that, in some individuals, the anorexia and metabolic changes of cachexia are driven by mediators produced either by the tumour directly or by the body in response to the tumour.

\section{Mediators of the cachectic state}

Cytokines, including tumour necrosis factor, interleukins- 1 and -6 , ciliary neurotrophic factor and interferon- $\gamma$ have been shown to induce some of the features of cachexia following 
administration to animals or human subjects (Michie et al. 1988; Starnes et al. 1988; Hellerstein et al. 1989; Strassmann et al. 1992; Espat et al. 1996). Elevated serum levels of tumour necrosis factor and interleukin-6 and the soluble receptors for tumour necrosis factor have been found in cancer patients, and in some instances these have correlated with severity of disease or weight loss (Aderka et al. 1991; Knapp et al. 1991; Kurzrock et al. 1993; Falconer et al. 1994; Preston et al. 1995; Staal-van den Brekel et al. 1995). However, often the pattern of symptoms and metabolic changes produced by exogenous cytokines differs from that of classical cachexia, and antibody-blocking experiments have shown only a limited ability to reverse these changes (Mahoney et al. 1988; Langstein \& Norton, 1991; McNamara et al. 1992). Thus, the relevance of cytokines within the circulation may only be limited. Increased production of tumour necrosis factor and interleukin- 6 by isolated peripheral-blood mononuclear cells of patients with cancer has also been observed and is in keeping with a local action for these cytokines (Aderka et al. 1985; Falconer et al. 1994). In pancreatic cancer such enhanced cytokine production correlates well with hypermetabolism and an acute-phase response (Falconer et al. 1994). Most of the pro-inflammatory cytokines, but primarily interleukin-6, have been shown to induce the hepatic acute-phase protein response (Heinrich et al. 1990; Oldenburg et al. 1993; O'Riordain et al. 1995; Espat et al. 1996). Thus, cytokines are likely to work in vivo at a local level through a complex network of interrelationships, they stimulate acute-phase protein production and probably also play a wider role in cachexia.

The source of pro-inflammatory cytokines in cancer cachexia is not clearly established. Tumour cells may produce pro-inflammatory cytokines themselves (Wigmore et al. 1994) and host peripheral-blood mononuclear cells may produce these cytokines in response to the presence of the tumour (Falconer et al. 1994). In addition there would appear to be amplification loops involving the tumour, with interaction of two or more cytokines (Yasumoto et al. 1995). It is also possible that the host further modulates the response to the cytokine network since neuroendocrine hormones will affect the production of acute-phase proteins (O'Riordain et al. 1995). Different clones of cancer cell lines produce similar patterns of cytokines in mouse models but have very different effects on host weight (Soda et al. 1994). It appears that this may be due to the production of other tumourspecific cachectic factors in association with conventional cytokines.

Changes in neuroendocrine hormone levels and targetorgan sensitivity are also observed in cachexia. In weightstable patients with pancreatic cancer, increased insulin secretion has been found with peripheral insulin resistance (Gullo et al. 1993). However, in trials in which weight-losing patients were included, a markedly reduced insulin response to feeding was seen. Changes in insulin production seem to be unrelated to loss of pancreatic tissue (Schwartz et al. 1978; Fox et al. 1985; Cersosimo et al. 1991). Elevated cortisol and glucagon levels have also been described (Schaur et al. 1979; Burt et al. 1983; Holroyde et al. 1984). These changes may be stimulated by cytokines (Michie $e t$ al. 1988; Starnes et al. 1988) and may tend to amplify the acute-phase response (Baumann \& Gauldie, 1994). Infusion of hydrocortisone or cortisol, glucagon and adrenalin in human subjects produces many of the features of the acutephase response, including increased energy expenditure, negative $\mathrm{N}$ balance, $\mathrm{C}$-reactive protein production and glucose intolerance (Bessey et al. 1984; Watters et al. 1986).

The role of leptin (the recently identified protein produced by adipocytes which regulates food intake and body weight) in cachexia remains to be clarified. The production and end-organ effects of leptin are modulated by cytokines and glucocorticoids, thus it may have a part to play in mediating cachexia (Grunfeld et al. 1996; Schwarz et al. 1997).

It is also possible that novel tumour-specific factors may mediate weight loss in cancer. A $24 \mathrm{kDa}$ glycoprotein found in the urine of cachectic cancer patients has recently been characterized. This causes enhanced skeletal muscle proteolysis when given to mice, and appears distinct from known cytokines (McDevitt et al. 1995; Todorov et al. 1996; Cariuk et al. 1997). A lipid-mobilizing factor similar to zinc-a $\mathrm{a}_{2}$ glycoprotein (an acute-phase protein) has also been isolated from the urine of cachectic cancer patients. This produces marked lipolysis in mouse models and in human adipocytes cultured in vitro (Tisdale, 1996).

\section{Treatment of weight loss in cancer}

The best way to cure cancer cachexia is to cure the cancer. However, this is only an option for the minority of patients. The next most obvious way to treat this phenomenon would be to supplement nutritional intake. However, studies of hyperalimentation in cancer cachexia using enteral or parenteral supplementation have been disappointing, producing only limited weight gain, mainly of water and fat (Nixon et al. 1981; Cohn et al. 1982; Evans et al. 1985; Klein et al. 1986; Lipman, 1991; Ng \& Lowry, 1991). Oral supplementation is often limited by anorexia and early satiety, but even when a limited increase in energy and $\mathrm{N}$ intake has been achieved this has not led to significant weight gain or clinical benefit (Oveson et al. 1993a).

Numerous other agents have been suggested to be useful in cachexia, such as the anti-serotoninergic agent cyproheptadine, the pro-kinetic agent metoclopramide, the corticosteroid dexamethasone, the progestogens medroxyprogesterone acetate and megestrol acetate, the gluconeogenesis inhibitor hydrazine sulphate and the psychotropic agent tetrahydrocannabinol, but none has lived up to its promise (Chlebowski et al. 1987; Beck \& Tisdale, 1989, 1990; McMillan et al. 1994; Nelson et al. 1994; Gebbia et al. 1996; Simons et al. 1996) and many of these agents have significant additional side-effects.

\section{n-3 Polyunsaturated fatty acids}

Eicosapentaenoic acid is the major metabolically-active $n-3$ fatty acid in man. It is made by marine algae and is found in the diet as a component of fish oil.

Fish oil supplements rich in $n-3$ fatty acids have been shown to reduce production of the cytokines interleukin-1, interleukin- 6 and tumour necrosis factor by mononuclear cells in normal volunteers, and this effect is maintained for some weeks after stopping supplementation (Endres et al. 1989; Cooper et al. 1993; Meydani et al. 1993). Fish oil also 
increases T-suppressor: helper cells, decreases T-cell proliferative response to mitogens, decreases the delayedhypersensitivity skin response and reduces neutrophil chemotaxis (Lee et al. 1985; Endres et al. 1989; Meydani et al. 1993; Calder, 1996).

Eicosapentaenoic acid has also been shown to inhibit fat and protein breakdown in animal models of cancer cachexia (Tisdale, 1996), and it has been suggested that this is due to inhibition of the end-organ effects of tumour-derived lipolytic and proteolytic factors. Furthermore, eicosapentaenoic acid may modify the response of hepatocytes to pro-inflammatory cytokines in terms of acute-phase protein production (Wigmore et al. 1997b).

Thus, it would seem that $n-3$ fatty acids can affect not only the production of pro-inflammatory mediators but also their end-organ effects. There are numerous mechanisms by which this may occur. Polyunsaturated fatty acids influence the activity of a number of receptors and enzymes which have a fundamental role in cellular signalling. When agonists stimulate receptors in the cell membrane they may activate adenylate cyclase ( $E C$ 4.6.1.1) or a phospholipase, the second messenger products of which (lipids in the case of phospholipases) influence the actions of cAMP-dependent protein kinase and protein kinase $\mathrm{C}$ respectively. $n-3$ Fatty acids have been shown to influence the effects of adenylate cyclase (Alam et al. 1988; Tisdale, 1993), phospholipase $A_{2}$ (EC 3.1.1.4) (Ballou \& Cheung, 1985), cAMP-dependent protein kinase (Speizer et al. 1991) and protein kinase C (Speizer et al. 1991; Holian \& Nelson, 1992). Eicosapentaenoic acid also binds to membrane voltage-sensitive $\mathrm{Na}$ channels and may alter the conductance of the channel (Kang \& Leaf, 1996), and $n-3$ fatty acids bind to the cytoplasmic glucocorticoid receptor at a site different from the hormonebinding site and markedly reduce its affinity for the hormone (Vallette et al. 1991; Sumida et al. 1993).

Other mechanisms by which $n-3$ fatty acids may modulate inflammation include interaction with peroxisome proliferator-activated receptor- $\alpha$ which is a gene transcription factor that induces the breakdown of leukotrienes and, thus, has a role in limiting the duration and extent of inflammation. A variety of polyunsaturated fatty acids, including eicosapentaenoic acid, and leukotrienes themselves appear to increase the activity of this factor (Keller et al. 1993; Devchand et al. 1996). Alternatively, the $\mathrm{C}_{20}$ polyunsaturated fatty acids are metabolized by cyclo-oxygenase into the prostanoids, prostaglandins and thromboxanes, and by 5-lipoxygenase ( $E C$ 1.13.11.12) into the leukotrienes. The $n-6$ fatty acid arachidonic acid is the major precursor for these substances in man and gives rise to the 2-series prostanoids (e.g. thromboxane $A_{2}$ and prostglandin $E_{2}$ and $I_{2}$ ) and the 4-series leukotrienes (leukotriene $\mathrm{B}_{4}, \mathrm{C}_{4} \mathrm{etc}$.). In contrast, eicosapentaenoic acid is also metabolized by these enzymes, but into the 3-series prostanoids and 5-series leukotrienes. Leukotrienes are involved in regulating inflammatory responses. 5-Series leukotrienes are less active and compete with those of the 4-series for binding sites, resulting in anti-inflammatory effects (Fischer \& Weber, 1983; Lee et al. 1985; Leaf \& Weber, 1988; Fitzgerald et al. 1989; Nordøy \& Dyerberg, 1989; Schmitt \& Dyerberg, 1989).

\section{Clinical studies using eicosapentaenoic acid-based preparations in cancer cachexia}

We have hypothesized that there is a block to the accretion of lean body mass in cachectic patients, in part, attributable to enhanced pro-inflammatory cytokine release. By downregulating cytokine production, fish oil or eicosapentaenoic acid supplementation should modulate this proinflammatory state. To test whether supplementation with fish oil could affect the progress of cachexia in patients with advanced pancreatic cancer we have conducted a study using Maxepa (Seven Seas, Hull, UK), a mixed marine triacylglycerol preparation containing $(\mathrm{g} / \mathrm{kg}) \quad 180$ eicosapentaenoic acid and 120 docosahexaenoic acid. This was given orally at a median dose of $12 \mathrm{~g} / \mathrm{d}$ (equivalent to $2 \mathrm{~g}$ eicosapentaenoic acid/d) to eighteen patients with unresectable pancreatic cancer. Before treatment, all patients were losing weight at a median rate of $2.9 \mathrm{~kg} /$ month. After supplementation for 3 months, patients had a median weight gain of $0.2 \mathrm{~kg} / \mathrm{month}$ with less than half the patients continuing to lose weight. There was no change in the percentage total body water over the period of the study. This regimen also produced a fall in the serum C-reactive protein level, suggesting that some of the metabolic abnormalities of pancreatic cancer can be reversed, resulting in the stabilization of weight (Wigmore et al. 1996b).

Subsequently we have examined the role of eicosapentaenoic acid alone in reversing cachexia. Twenty-seven patients with unresectable pancreatic cancer were given $6 \mathrm{~g}$ eicosapentaenoic acid (95\% pure)/d orally after a 4-week dose-escalation period. Patients were losing a median of $2.0 \mathrm{~kg} /$ month at baseline. After 4 weeks patients had a median weight gain of $0.75 \mathrm{~kg}$, and this effect remained at 3 months with a median weight gain of $0.25 \mathrm{~kg} /$ month. Again, there was no change in the percentage total body water over the course of the study, confirming that the achievement of weight stability was not due to changes in hydration (Barber et al. 1997). There were no serious side-effects in these studies and median survival was approximately 7 months.

A subgroup of six patients from the latter study underwent measurement of interleukin- 6 and tumour necrosis factor production in peripheral-blood mononuclear cells ex vivo and of the acute-phase protein response in vivo before and after the administration of eicosapentaenoic acid for the 1-month dose-escalation period. These patients showed a significant fall in their mononuclear cell production of pro-inflammatory cytokines and a fall in the level of the acute-phase response as measured by $\mathrm{C}$-reactive protein (Wigmore et al. 1996a, 1997a).

Eicosapentaenoic acid, therefore, would seem capable of arresting the further development of cachexia in patients with advanced pancreatic cancer. This may be related specifically to the down-regulation of pro-inflammatory cytokinemediated metabolic events. Perhaps more likely, however, is a complex interaction between eicosapentaenoic acid and the production or end-organ effects of (a) protein and lipid mediators of the inflammatory response, (b) tumour-specific catabolic mediators and (c) counter-regulatory neuroendocrine hormones. 


\section{Conclusion}

The previously described phase 1 and 2 clinical studies with eicosapentaenoic acid in patients with cancer cachexia point to a potential role for lipids as modulators of the wasting process. The precise contribution from the specific and non-specific components of the immune system to the generation of the inflammatory mediators involved in cancer cachexia in human subjects is poorly understood. However, if current randomized phase 3 studies with eicosapentaenoic acid prove effective, then this should at least provide a model for further study of the interaction between lipids and the role of the immune system in the wasting associated with a variety of human diseases.

\section{References}

Aderka D, Engelmann H, Hornik V, Skornick Y, Levo Y, Wallach D \& Kushtai G (1991) Increased serum levels of soluble receptors for tumor necrosis factor in cancer patients. Cancer Research $5,5602-5607$.

Aderka D, Fisher S, Levo Y, Holtmann H, Hahn T \& Wallach D (1985) Cachectin/tumour-necrosis-factor production by cancer patients. Lancet ii, 1190 .

Alam SQ, Ren YF \& Alam BS (1988) ( $\left.{ }^{3} \mathrm{H}\right)$ forskolin- and $\left({ }^{3} \mathrm{H}\right)$ dihydroalprenolol-binding sites and adenylate cyclase activity in heart of rats fed diets containing different oils. Lipids $\mathbf{2 3}$, 207-213.

Ballou LR \& Cheung WY (1985) Inhibition of human platelet phospholipase $\mathrm{A}_{2}$ activity by unsaturated fatty acids. Proceedings of the National Academy of Sciences USA 82, 371-375.

Barber MD, Wigmore SJ, Ross JA \& Fearon KCH (1997) Eicosapentaenoic acid attenuates cachexia associated with advanced pancreatic cancer. Prostaglandins Leukotrienes and Essential Fatty Acids 57, 204.

Baumann H \& Gauldie J (1994) The acute phase response. Immunology Today 15, 74-80.

Beck SA \& Tisdale MJ (1989) Effect of insulin on weight loss and tumour growth in a cachexia model. British Journal of Cancer $\mathbf{5 9 , 6 7 7 - 6 8 1 . ~}$

Beck SA \& Tisdale MJ (1990) Effect of megestrol acetate on weight loss induced by tumour necrosis factor $\alpha$ and a cachexia-inducing tumour (MAC16) in NMRI mice. British Journal of Cancer 62, 420-424.

Bessey PQ, Watters JM, Aoki TT \& Wilmore DW (1984) Combined hormonal infusion simulates the metabolic response to injury. Annals of Surgery 200, 264-281.

Brennan MF (1977) Uncomplicated starvation versus cancer cachexia. Cancer Research 37, 2359-2364.

Burt ME, Aoki TT, Gorschboth CM \& Brennan MF (1983) Peripheral tissue metabolism in cancer-bearing man. Annals of Surgery 198, 685-691.

Calder PC (1996) Immunomodulatory and anti-inflammatory effects of $n-3$ polyunsaturated fatty acids. Proceedings of the Nutrition Society 55, 737-774.

Cangiano C, Laviano A, Muscaritoli M, Meguid MM, Cascino A \& Fanelli FR (1996) Cancer anorexia: New pathogenic and therapeutic insights. Nutrition 12, Suppl.1, S48-S51.

Cariuk P, Lorite MJ, Todorov PT, Field WN, Wigmore SJ \& Tisdale MJ (1997) Induction of cachexia in mice by a product isolated from the urine of cachetic cancer patients. British Journal of Cancer 76, 606-613.

Cersosimo E, Pisters PWT, Pesola G, McDermott K, Bajorunas D \& Brennan MF (1991) Insulin secretion and action in patients with pancreatic cancer. Cancer 67, 486-493.
Chlebowski RT, Bulcavage L, Grosvenor M, Tsunokai R, Block JB, Heber D, Scrooc M, Chlebowski JS, Chi J, Oktay E, Akman S \& Ali I (1987) Hydrazine sulphate in cancer patients with weight loss. A placebo-controlled clinical experience. Cancer $\mathbf{5 9}$, 406-410.

Chlebowski RT, Heber D \& Block JB (1982) Serial assessment of glucose metabolism in patients with cancer cachexia. Clinical Research 30, 69A.

Cohn SH, Vartsky D, Vaswani AN, Sawitsky A, Rai K, Gartenhaus W, Yasumura S \& Ellis KJ (1982) Changes in body composition of cancer patients following combined nutritional support. Nutrition and Cancer 4, 107-119.

Cooper AL, Gibbons L, Horan MA, Little RA \& Rothwell NJ (1993) Effect of dietary fish oil supplementation on fever and cytokine production in human volunteers. Clinical Nutrition 12, 321-328.

Devchand PR, Keller H, Peters JM, Vazquez M, Gonzalez FJ \& Wahli W (1996) The PPAR $\alpha$-leukotriene $B_{4}$ pathway to inflammation control. Nature 384, 39-43.

DeWys WD, Begg C, Lavin PT, Band PR, Bennett JM, Bertino JR, Cohen MH, Douglass HO, Engstrom PF, Ezdinli EZ, Horton J, Johnson GJ, Moertel CG, Oken MM, Perlia C, Rosenbaum C, Silverstein MN, Skeel RT, Sponzo RW \& Tormey DC (1980) Prognostic effect of weight loss prior to chemotherapy in cancer patients. American Journal of Medicine 69, 491-497.

Edén E, Edström S, Bennegård $\mathrm{K}$, Scherstén $\mathrm{T}$ \& Lundholm $\mathrm{K}$ (1984) Glucose flux in relation to energy expenditure in malnourished patients with and without cancer during periods of fasting and feeding. Cancer Research 44, 1718-1724.

Endres S, Ghorbani R, Kelley VE, Georgilis K, Lonnemann G, van der Meer JWM, Cannon JG, Rogers TS, Klempner MS, Weber PC, Schaefer EJ, Wolff SM \& Dinarello CA (1989) The effect of dietary supplementation with $n-3$ polyunsaturated fatty acids on the synthesis of interleukin-1 and tumor necrosis factor by mononucleat cells. New England Journal of Medicine 320, 265-271.

Espat NJ, Auffenberg T, Rosenberg JJ, Rogy M, Martin D, Fang CH, Hasselgren PO, Copeland EM \& Moldawer LL (1996) Ciliary neurotrophic factor is catabolic and shares with IL-6 the capacity to induce an acute phase response. American Journal of Physiology 271, R185-R190.

Evans WK, Makuch R, Clamon GH, Feld R, Weiner RS, Moran E, Blum R, Shepherd FA, Jeejeebhoy KN \& De Wyss WD (1985) Limited impact of total parenteral nutrition on nutritional status during treatment for small cell lung cancer. Cancer Research $\mathbf{4 5}$, 3347-3353.

Falconer JS, Fearon KCH, Plester CE, Ross JA \& Carter DC (1994) Cytokines, the acute-phase response, and resting energy expenditure in cachectic patients with pancreatic cancer. Annals of Surgery 219, 325-331.

Falconer JS, Fearon KCH, Ross JA, Elton R, Wigmore SJ, Garden OJ \& Carter DC (1995) Acute-phase protein response and survival duration of patients with pancreatic cancer. Cancer $\mathbf{7 5}$, 2077-2082.

Fearon KCH \& Carter DC (1988) Cancer cachexia. Annals of Surgery 208, 1-5.

Fearon KCH, Hansell DT, Preston P, Plumb JA, Davies J, Shapiro D, Shenkin A, Calman KC \& Burns HJG (1988) Influence of whole body protein turnover rate on resting energy expenditure in patients with cancer. Cancer Research 48, 2590-2595.

Fischer S \& Weber PC (1983) Thromboxane $\mathrm{A}_{3}\left(\mathrm{TXA}_{3}\right)$ is formed in human platelets after dietary eicosapentaenoic acid (C20 : 5w3). Biochemical and Biophysical Research Communications 116, 1091-1099. 
Fitzgerald GA, Braden G, Fitzgerald DJ \& Knapp HR (1989) Fish oils in cardiovascular disease. Journal of Internal Medicine $\mathbf{2 2 5}$, Suppl. 1, 25-29.

Fox JN, Frier, BM, Armitage M \& Ashby JP (1985) Abnormal insulin secretion in carcinoma of the pancreas: response to glucagon stimulation. Diabetic Medicine 2, 113-116.

Gebbia V, Testa A \& Gebbia N (1996) Prospective randomised trial of two dose levels of megestrol acetate in the management of anorexia-cachexia syndrome in patients with metastatic cancer. British Journal of Cancer 73, 1576-1580.

Grunfeld C \& Feingold LH (1992) Metabolic disturbances and wasting in the acquired immunodeficiency syndrome. New England Journal of Medicine 327, 329-337.

Gunfeld C, Zhao C, Fuller J, Pollock A, Moser A, Freidman J \& Feingold KR (1996) Endotoxin and cytokines induce expression of leptin, the ob gene product, in hamsters. A role for leptin in the anorexia of infection. Journal of Clinical Investigation 97, 2152-2157.

Gullo L, Ancona D, Pezzilli R, Casadei R \& Campione O (1993) Glucose tolerance and insulin secretion in pancreatic cancer. Italian Journal of Gastroenterology 25, 487-489.

Heinrich PC, Castell JV \& Andus T (1990) Interleukin-6 and the acute phase response. Journal of Biochemistry 265, 621-636.

Hellerstein MK, Meydani SN, Meydani M, Wu K \& Dinarello CA (1989) Interleukin-1-induced anorexia in the rat. Influence of prostaglandins. Journal of Clinical Investigation 84, 228-235.

Holian O \& Nelson R (1992) Action of long-chain fatty acids on protein kinase $C$ activity: Comparison of omega- 6 and omega-3 fatty acids. Anticancer Research 12, 975-980.

Holroyde CP, Skutches CL, Boden G \& Reichard GA (1984) Glucose metabolism in cachectic patients with colorectal cancer. Cancer Research 44, 5910-5913.

Jeevanandam M, Horowitz GD, Lowry SF \& Brennan MF (1986) Cancer cachexia and the rate of whole body lipolysis in man. Metabolism 35, 304-310.

Kang IX \& Leaf A (1996) Evidence that free polyunsaturated fatty acids modify $\mathrm{Na}^{+}$channels by directly binding to the channel proteins. Proceedings of the National Academy of Sciences USA 93, 3542-3546.

Keller H, Dreyer C, Medin J, Mahfoudi A, Ozato K \& Wahli W (1993) Fatty acids and retinoids control lipid metabolism through activation of peroxisome proliferator-activated receptor-retinoid $\mathrm{X}$ receptor heterodimers. Proceedings of the National Academy of Sciences USA 90, 2160-2164.

Klein S, Simes J \& Blackburn GL (1986) Total parenteral nutrition and cancer clinical trials. Cancer 58, 1378-1386.

Knapp ML, Al-Sheibani S, Riches PG, Hanham IWF \& Phillips RH (1991) Hormonal factors associated with weight loss in patients with advanced breast cancer. Annals of Clinical Biochemistry 28 , 480-486

Kurzrock R, Redman J, Cabanillas F, Jones D, Rothberg J \& Talpaz M (1993) Serum interleukin 6 levels are elevated in lymphoma patients and correlate with survival in advanced Hodgkin's disease and with B symptoms. Cancer Research 53, 2118-2122.

Langstein HN \& Norton JA (1991) Mechanisms of cancer cachexia. Hematology Oncology Clinics of North America 5, 103-123.

Leaf A \& Weber PC (1988) Cardiovascular effects of n-3 fatty acids. New England Journal of Medicine 318, 549-557.

Lee TH, Hoover RL, Williams JD, Sperling RI, Ravalese J, Spur BW, Robinson DR, Corey EJ, Lewis RA \& Austin KF (1985) Effect of dietary enrichment with eicosapentaenoic and docosahexaenoic acids on in vitro neutrophil and monocyte leukotriene generation and neutrophil function. New England Journal of Medicine 312, 1217-1224.
Lipman TO (1991) Clinical trials of nutritional support in cancer. Parenteral and enteral therapy. Hematology Oncology Clinics of North America 5, 91-102.

McDevitt TM, Todorov PT, Beck SA, Khan, SH \& Tisdale MJ (1995) Purification and characterisation of a lipid-mobilising factor associated with cachexia-inducing tumors in mice and humans. Cancer Research 55, 1458-1463.

McMillan DN, Simpson JM, Preston T, Watson WS, Fearon KCH, Shenkin A, Burns HJG \& McArdle CS (1994) Effect of megestrol acetate on weight loss, body composition and blood screen of gastrointestinal cancer patients. Clinical Nutrition 13, $85-89$.

McNamara MJ, Alexander HR \& Norton JA (1992) Cytokines and their role in the pathophysiology of cancer cachexia. Journal of Parenteral and Enteral Nutrition 16, Suppl., 50S-55S.

Mahoney SM, Beck SA \& Tisdale MJ (1988) Comparison of weight loss induced by recombinant tumour necrosis factor with that produced by a cachexia-inducing tumour. British Journal of Cancer 57, 385-389.

Melville S, McNurlan MA, Calder AG \& Garlick PJ (1990) Increased protein turnover despite normal energy metabolism and responses to feeding in patients with lung cancer. Cancer Research 50, 1125-1131.

Meydani SN, Lichtenstein AH, Cornwall S, Meydani M, Goldin BR, Rasmussen H, Dinarello CA \& Schaefer EJ (1993) Immunological effects of National Cholesterol Education Panel Step-2 diets with and without fish-derived n-3 fatty acid enrichment. Journal of Clinical Investigation 92, 105-113.

Michie HR, Spriggs DR, Manogue KR, Sherman ML, Revhaug A, O'Dwyer ST, Arthur K, Dinarello CA, Cerami A, Wolff SM, Kufe DW \& Wilmore DW (1988) Tumor necrosis factor and endotoxin induce similar metabolic responses in human beings. Surgery 104, 280-286.

Nelson KA, Walsh D \& Sheehan FA (1994) The cancer anorexiacachexia syndrome. Journal of Clinical Oncology 12, 213-225.

$\mathrm{Ng} \mathrm{EH} \mathrm{\&} \mathrm{Lowry} \mathrm{SF} \mathrm{(1991)} \mathrm{Nutritional} \mathrm{support} \mathrm{and} \mathrm{cancer}$ cachexia. Evolving concepts of mechanisms and adjunctive therapies. Hematology Oncology Clinics of North America 5, 161-184.

Nixon DW, Lawson DH, Kutner M, Ansley J, Schwarz M, Heymsfield S, Chawla R, Cartwright TH \& Rudman D (1981) Hyperalimentation of the cancer patient with protein-calorie undernutrition. Cancer Research 41, 2038-2045.

Nordøy A \& Dyerberg J (1989) n-3 Fatty acids in health and disease. Journal of Internal Medicine 225, Suppl. 1, 1-3.

Oldenburg HSA, Rogy MA, Lazarus DD, Van Zee KJ, Keeler BP, Chizzonite RA, Lowry SF \& Moldawer LL (1993) Cachexia and the acute-phase protein response in inflammation are regulated by interleukin-6. European Journal of Immunology 23, 1889-1894.

O'Riordain MG, Ross JA, Fearon KCH, Maingay J, Farouk M, Garden OJ \& Carter DC (1995) Insulin and counterregulatory hormones influence acute-phase protein production in human hepatocytes. American Journal of Physiology 269, E323-E330.

Oveson L, Allingstrup L, Hannibal J, Mortensen EL \& Hansen OP (1993a) Effect of dietary counseling on food intake, body weight, response rate, survival, and quality of life in cancer patients undergoing chemotherapy: A prospective, randomised study. Journal of Clinical Oncology 11, 2043-2049.

Oveson L, Hannibal J \& Mortensen EL (1993b) The interrelationship of weight loss, dietary intake, and quality of life in ambulatory patients with cancer of the lung, breast, and ovary. Nutrition and Cancer 19, 159-167.

Preston T, Fearon KCH, McMillan DC, Winstanley FP, Slater C, Shenkin A \& Carter DC (1995) Effect of ibuprofen on the 
acute-phase response and protein metabolism in patients with cancer and weight loss. British Journal of Surgery $\mathbf{8 2}$, 229-234.

Reeds PJ, Fjeld CR \& Jahoor F (1994) Do the differences between the amino acid compositions of acute-phase and muscle proteins have a bearing on nitrogen loss in traumatic states? Journal of Nutrition 124, 906-910.

Roubenoff R, Roubenoff RA, Ward LM, Holland SM \& Hellman DB (1992) Rheumatoid cachexia: Depletion of lean body mass in rheumatoid arthritis. Possible association with tumor necrosis factor. Journal of Rheumatology 19, 1505-1510.

Schaur RJ, Fellier H, Gleispach H, Fink E \& Kronberger L (1979) Tumor host relations. I. Increased plasma cortisol in tumorbearing humans compared with patients with benign surgical diseases. Journal of Cancer Research Clinical Oncology 93, 281-285.

Schmitt EB \& Dyerberg J (1989) n-3 Fatty acids and leukocytes. Journal of Internal Medicine 225, Suppl. 1, 151-158.

Schwartz SS, Zeidler A, Moosa AR, Kuku SF \& Rubenstein AH (1978) A prospective study of glucose tolerance, insulin, C-peptide, and glucagon responses in patients with pancreatic carcinoma. Digestive Disorders 23, 1107-1114.

Schwarz MW, Seeley RJ \& Woods SC (1997) Wasting illness as a disorder of body weight regulation. Proceedings of the Nutrition Society 56, 785-791.

Shaw JHF \& Wolfe RR (1987) Glucose and urea kinetics in patients with early and advanced gastrointestinal cancer: The response to glucose infusion, parenteral feeding, and surgical resection. Surgery 101, 181-191.

Simons JPFHA, Aaronson NK, Vansteenkiste JF, ten Velde GPM, Muller MJ, Drenth BM, Erdkamp FLG, Cobben EGM, Schoon EJ, Smeets JBE, Schouten HC, Demedts M, Hillen HFP, Blijham GH \& Wouters EFM (1996) Effects of medroxyprogesterone acetate on appetite, weight, and quality of life in advanced-stage non-hormone-sensitive cancer: A placebo-controlled multicenter study. Journal of Clinical Oncology 14, 1077-1084.

Soda K, Kawakami M, Kashii A \& Miyata M (1994) Characterization of mice bearing subclones of colon 26 adenocarcinoma disqualifies interleukin- 6 as the sole inducer of cachexia. Japanese Journal of Cancer Research 85, 1124-1130.

Speizer LA, Watson MJ \& Brunton LL (1991) Differential effects of omega-3 fish oils on protein kinase activities in vitro. American Journal of Physiology 261, E109-E114.

Staal-van den Brekel AJ, Dentener MA, Schols AMWJ, Buurman WA \& Wouters EFM (1995) Increased resting energy expenditure and weight loss are related to a systemic inflammatory response in lung cancer patients. Journal of Clinical Oncology 13, 2600-2605.

Starnes HF, Warren RS, Jeevanandam M, Gabrilove JL, Larchian W, Oettgen, HF \& Brennan MF (1988) Tumor necrosis factor and the acute metabolic response to tissue injury in man. Journal of Clinical Investigation 82, 1321-1325.

Strassmann G, Fong M, Kenney JS \& Jacob CO (1992) Evidence for the involvement of interleukin 6 in experimental cancer cachexia. Journal of Clinical Investigation 89, 1681-1684.

Sumida C, Vallette G \& Nune EA (1993) Interaction of unsaturated fatty acids with rat liver glucocorticoid receptors: studies to localise the site of interaction. Acta Endocrinologica 129, 348-355.

Tisdale MJ (1993) Mechanism of lipid mobilisation associated with cancer cachexia: Interaction between the polyunsaturated fatty acid, eicosapentaenoic acid, and inhibitory guanine nucleotide-regulatory protein. Prostaglandins Leukotrienes and Essential Fatty Acids 48, 105-109.

Tisdale MJ (1996) Induction of lipolysis and muscle protein degradation by EPA in cancer cachexia. Nutrition 12, Suppl., 531-533.

Todorov P, Cariuk P, McDevitt T, Coles B, Fearon KCH \& Tisdale M (1996) Characterisation of a cancer cachectic factor. Nature 379, 739-742.

Vallette G, Vanet A, Sumida C \& Nunez EA (1991) Modulatory effects of unsaturated fatty acids on the binding of glucocorticoids to rat liver glucocorticoid receptors. Endocrinology 129, 1363-1369.

Vlassara H, Spiegel RJ, San Doval D \& Cerami A (1986) Reduced plasma lipoprotein lipase activity in patients with malignancyassociated weight loss. Hormone and Metabolic Research 18 698-703.

Warren S (1935) The immediate causes of death in cancer. American Journal of Medical Sciences 184, 610-616.

Watters JM, Bessey PQ, Dinarello CA, Wolff SM \& Wilmore DW (1986) Both inflammatory and endocrine mediators stimulate host responses to sepsis. Archives of Surgery 121, 179-190.

Wigmore SJ, Fearon KCH, Maingay JP \& Ross JA (1997a) Downregulation of the acute-phase response in patients with pancreatic cancer cachexia receiving oral eicosapentaenoic acid is mediated via suppression of interleukin-6. Clinical Science 92, 215-221.

Wigmore SJ, Fearon KCH \& Ross JA (1997b) Modulation of human hepatocyte acute phase protein production in vitro by $\mathrm{n}-3$ and n-6 polyunsaturated fatty acids. Annals of Surgery 225, $103-111$.

Wigmore SJ, Fearon KCH, Ross JA \& Carter DC (1996a) Eicosapentaenoic acid, cytokines and the acute-phase protein response in pancreatic cancer. British Journal of Surgery 83, 1649-1650.

Wigmore SJ, Plester CE, Richardson RA \& Fearon KCH (1997c) Changes in nutritional status associated with unresectable pancreatic cancer. British Journal of Cancer 75, 106-109.

Wigmore SJ, Plester CE, Ross JA \& Fearon KCH (1997d) Contribution of anorexia and hypermetabolism to weight loss in anicteric patients with pancreatic cancer. British Journal of Surgery 84, 196-197.

Wigmore SJ, Ross JA, Falconer JS, Plester CE, Tisdale MJ, Carter DC \& Fearon KCH (1996b) The effect of polyunsaturated fatty acids on the progress of cachexia in patients with pancreatic cancer. Nutrition 12, Suppl., S27-S30.

Wigmore SJ, Ross JA, Fearon KCH, Maingay JP \& Carter DC (1994) Pancreatic cancer cells stimulate C-reactive protein production in isolated hepatocytes via IL-6 or IL-8. British Journal of Surgery 81, 1814.

Yasumoto K, Mukaida N, Harada A, Kumo K, Akiyamn M, Nahashima E, Fujioka N, Mai M, Kashahara T, Fujimoto-Ouchi K, Mori K, Tanaka Y \& Matsuhima K (1995) Molecular analysis of the cytokine network involved in cachexia in colon 26 adenocarcinoma-bearing mice. Cancer Research 35, 921-927. 